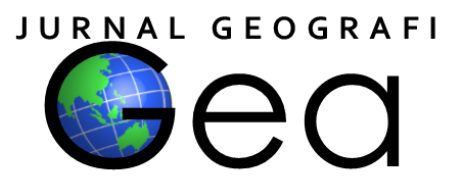

\title{
LANDSLIDE VULNERABILITY-BASED DISASTER MITIGATION PLANNING IN THE ELEMENTARY SCHOOL ENVIRONMENT OF BOYOLALI REGENCY
}

\author{
Kuny Hidayah', Novita Nur Azizah², Fauzia Rahman Hamid ${ }^{3}$, Muchammad Alfa \\ Aqimuddin $^{4}$, Radix Dzakiya Ahmad ${ }^{5}$, Yunus Aris Wibowo \\ 1,2,3,4,5,6 Geography Education Department, Faculty of Teacher Training and Education, \\ Universitas Muhammadiyah Surakarta \\ ${ }^{1}$ Kunyhdy3@ gmail.com, ${ }^{2}$ a610180014@ @ student.ums.ac.id, ${ }^{3}$ a610182007@ student.ums.ac.id, \\ 4a610180062@student.ums.ac.id, 5a610180063@student.ums.ac.id, 6yaw222@ums.ac.id
}

\begin{abstract}
Land sliding is a disaster that is potentially harmful to the community. Education facilities are severely vulnerable to landslides. Consequently, this study focused on analyzing the environmental vulnerability of elementary education in the landslides-prone area in the Boyolali Regency as a basis for disaster mitigation planning. The population in this study were all primary schools in the landslides-prone area of the Boyolali Regency. The sampling technique was conducted by using purposive sampling. The school sample was determined based on the location in the landslides-prone area of the Boyolali Regency, the location of the school based on the slope, and the similarity of Accreditation from the Indonesian Ministry of Education and Culture. Respondents in this study were the principal and permanent teachers in each sample school. The data analysis in this research was done by using descriptive statistics. The analysis of the vulnerability of elementary education was obtained from the results of questionnaires and interviews which have been validated by field surveys. These results were used as the basis for landslide disaster mitigation planning. The indicators of vulnerability in this study are policies, facilities and infrastructure, knowledge, and structure of school buildings. The results of data analysis showed that the three sample schools belonged to three different vulnerability classes. The findings were that the level of vulnerability of the elementary education environment was not in line with the location of the school in the landslides-prone area of Boyolali Regency and the slope. Ngadirojo elementary school 1 (SDN 1) was located on a gentle slope but had a high level of vulnerability because of low preparedness. Jlarem elementary school 2 (SDN 2) was on a rather steep slope with a moderate level of vulnerability because of its good preparedness. Furthermore, Ngagrong elementary school 2 (SDN 2) was on a steep slope but had high preparedness so that its level of vulnerability was low.
\end{abstract}

Keywords: Disaster, Mitigation, Landslides, Education, Elementary School.

\section{INTRODUCTION}

The character of Indonesia in terms of geographical, geological, hydrometeorological, and demographic conditions causes Indonesia's territory to be potentially exposed to disasters. According to Indonesian Law no. 24 of 2007 disaster is an event or series of events that threatens and disrupts the life and livelihood of the community which is caused both by natural factors and/or non-natural factors as well as human factors resulting in human casualties, environmental damage, property loss, and psychological impacts. According to (UNISDR, 2009) disasters can be caused by geological, hydrometeorological, natural, and biological hazards. One of the hydrometeorological hazards that often threaten Indonesian territory is landslides.

Landslides are one of the disasters that frequently hit parts of Indonesia. It is defined as a form of mass transfer of ground motion, rock or soil, and rock debris that occurs suddenly moving down the slope which is 
influenced by the force of gravity (Paimin \& Pramono, 2009; Pourghasemi, Gayen, Edalat, Zarafshar, \& Tiefenbacher, 2020). According to (Istijono, Hakam, \& Ophiyandri, 2016; Kazeev \& Postoev, 2017) landslide is a process in a stress-stretching state of slope soil mass to separate soil mass movement from slope motion. According to (Cruden \& Varnes, 1996) there are three types of landslides, namely fall, slide and flow types. A common symptom when a landslide occurs is the appearance of cracks on the slopes parallel to the direction of the cliffs that ordinarily occur after rain. Landslides can occur due to extreme daily rainfall before the event, volcanic rock types with very high weathering that form a thick layer of soil, steep slopes ( $\mathrm{Li}, \mathrm{Chu}, \& \mathrm{Yu}$, 2019; Naryanto, Prawiradisastra, Ardiyanto, \& Hidaya, 2020; Pourghasemi et al., 2020; Singh, 2009, 2010; Susilo, Fitriah, Sunaryo, Ayu Rachmawati, \& Suryo, 2020; Zhou \& Sun, 2019). Consequently, landslides will have various impacts on human, animal, and plant life (Zhou \& Sun, 2019).

The impact of landslides can be divided into two types, namely the impact on life and the environment. The impact on life, namely the loss of a person's life and injuries to someone due to landslides occurred in areas with high population density, besides that landslides also resulted in property losses (Makajić-Nikolić, 2020; Mohamed Shaluf, 2007; Pourghasemi et al., 2020; Singh, 2010; Zhou \& Sun, 2019). Furthermore, the impact on the environment is environmental damage such as loss of land cover vegetation, disruption of environmental ecosystems, depletion of water reserves due to critical land. For instance, the loss of vegetation in a forest will result in a greater acceleration of the rate of erosion and landslides (Alimohammadlou, Najafi, \& Yalcin, 2013; Singh, 2010).

Landslides are threatening not only the settlements and public facilities, but they are also threatening the existence of educational facilities such as schools located in disasterprone areas (KRB) (Paudel, Omura, Kubota, \& Morita, 2003). The impact of landslides on education is the damage to school buildings, as well as psychological impacts on students, school principals, teachers, and staff (Chen \& Lee, 2012). Consequently, education on disaster mitigation is crucial to be conveyed, especially for the school community and stakeholders (Shiwaku \& Fernandez, 2011; Shiwaku, Shaw, Kandel, Shrestha, \& Dixit, 2007). So that, these communities have a thorough disaster mitigation preparation and planning (Shaw \& Tran, 2012; Tran, Kaneko, Shaw, Victoria, \& Oi, 2009; Wibowo, Dewi, Ronggowulan, Anjarsari, \& Miftakhunisa, 2020; Wibowo et al., 2019).

Disaster mitigation education can be carried out by integrating disaster material into learning materials of extracurricular and cocurricular. Some subjects that are appropriate for the delivery of material disaster are geography, sociology, Indonesian, history, and local content (Rizaldy, 2018). If a child is taught disaster preparedness, it will bring revolutionaries to the community because they are the future for villages and schools (Benson \& Bugge, 2007; Doocy, Russell, Gorokhovich, \& Kirsch, 2013; Ray-Bennett \& Shiroshita, 2019).

The Boyolali Regency is one of the regencies in Central Java province which potentially affected Landslide. Physically, the Boyolali Regency has an area that includes the slopes of the Merapi Volcano where this area has a very varied slope level. Based on BNPB (2020), two landslide incidents occurred in Boyolali Regency during 2019. The incident occurred in Ampel District and resulted in damage to residents' houses and closed roads to the affected villages.

Based on theoretical and empirical facts, this research is crucial to carry out to know how far schools have a landslide disaster mitigation planning, especially schools located in landslide-prone areas. This research is still rarely conducted because most research on landslides only examines hazards, vulnerabilities, risks, and impacts in general. This study analyzes the vulnerability of schools in landslide-prone areas based on policy indicators, facilities and infrastructure, knowledge, and school building conditions. Furthermore, this study aims to analyze the vulnerability of the primary school education environment at landslide-prone areas in the Boyolali Regency. This research was conducted in SDN 2 Jlarem, SDN 1 Ngadirejo, and SDN 2 Ngagrong which were selected 
based on the slope and landslide-prone areas map of Boyolali Regency. The expected result of this research is the formation of landslide disaster mitigation education for elementary schools located in landslide-prone areas.
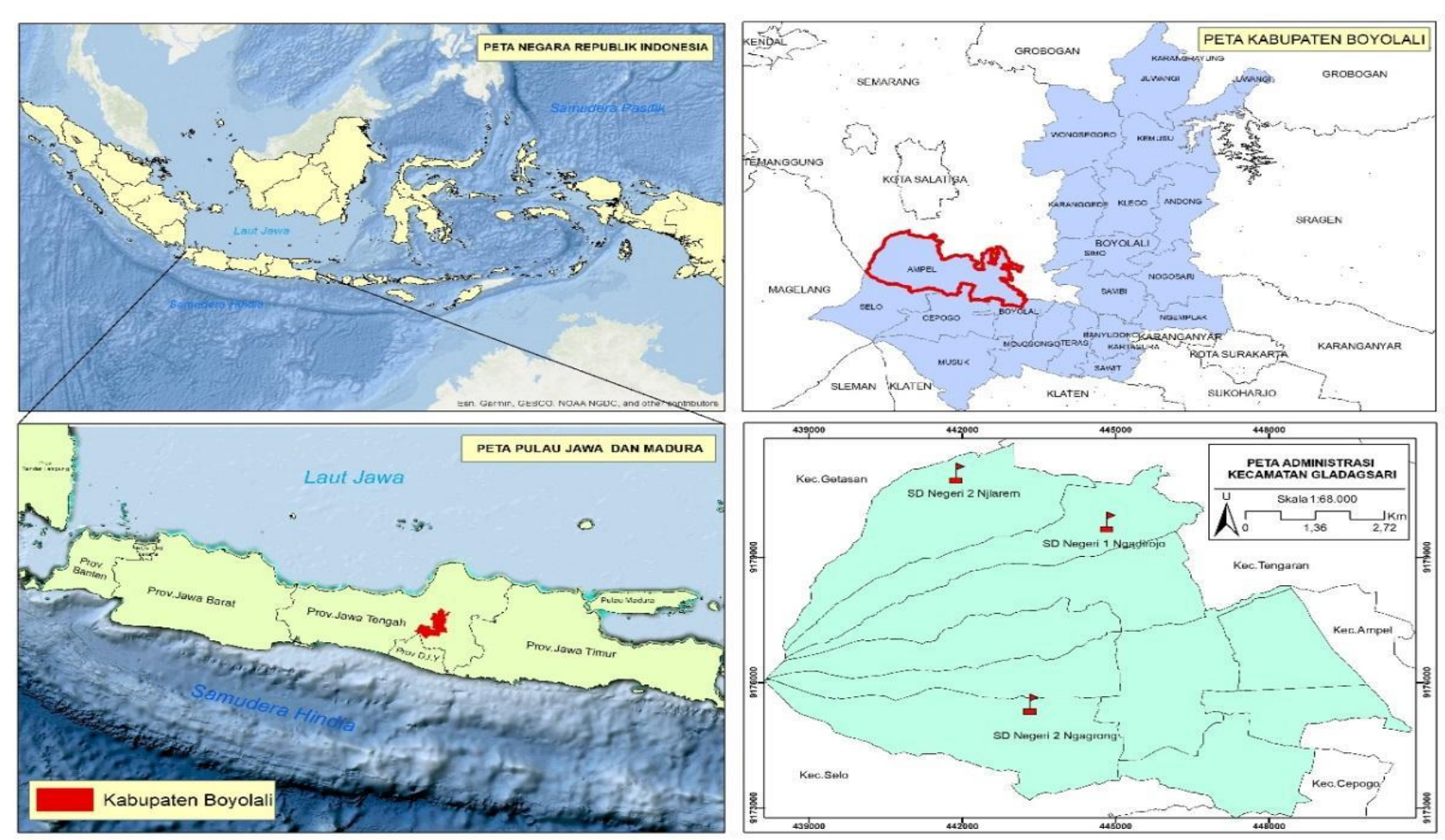

Figure 1. Research Area

The study was conducted for five months from September 2020 to January 2021. The population in this study were all primary schools in KRB landslide, Boyolali Regency. The sampling technique used in this study was purposive sampling. The schools that were sampled had the criteria of being in a different class of slope, being in landslide-prone areas, and having the same accreditation from the Ministry of Education and Culture. The respondents from each school were principals and teachers who registered as Civil Servants (PNS) because they have a stronger role than teachers who are not registered as PNS. The instrument used in this study was a closedended questionnaire based on four indicators, namely knowledge of school policy determinants (school principals and teachers), school disaster mitigation policies, facilities, and infrastructure (Table 1). Also, interviews were conducted with respondents to refine the answers given through questionnaires.

\section{RESEARCH METHOD}

This study used a quantitative approach. The design of this research was a survey with the analysis unit as the slope of the slope. The research was carried out in elementary schools in KRB landslides in Gladagsari District, Boyolali Regency, Central Java (Figure 1).

The data analysis used descriptive statistics. The results of filling out the questionnaire by the respondents were given a score and then classified using the equal step technique to obtain the vulnerability class of each school to landslides. Scores are given based on the availability of mitigation forms for landslides in elementary schools which are the research subjects. Therefore, the higher the score, the lower level of vulnerability obtained, while the lower the score, the higher the vulnerability class (Table 2). The scores for each parameter from each indicator are summed to get the class of vulnerability. $\mathrm{I}=$ Range $/ \mathrm{K}$

\begin{tabular}{|c|c|}
\hline I & $=$ Interval \\
\hline Range & $\begin{array}{l}=\text { the largest data value }- \text { the } \\
\text { smallest data value }\end{array}$ \\
\hline K & $=$ Number of Classes \\
\hline
\end{tabular}


Table 1. Indicators on Elementary School Environmental Vulnerability Variables

\begin{tabular}{ccc}
\hline No. & Indicator & Number of questions \\
\hline 1 & Policy & 22 \\
2 & Facilities and infrastructure & 10 \\
3 & Knowledge & 40 \\
4 & School Building Structures & 20 \\
\hline
\end{tabular}

Table 2. Data Analysis Technique

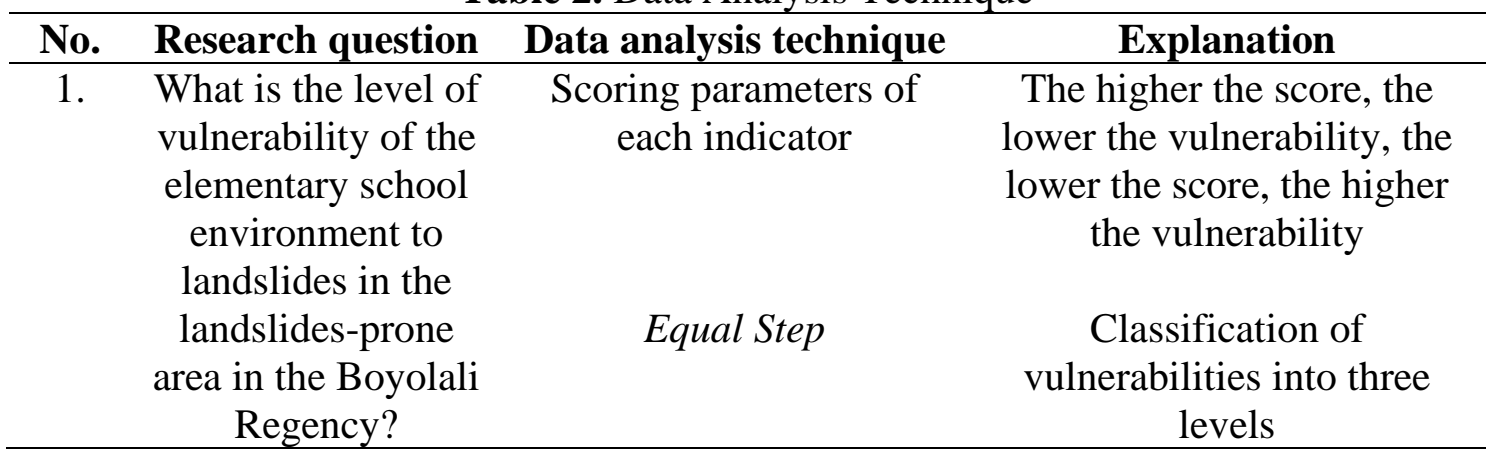

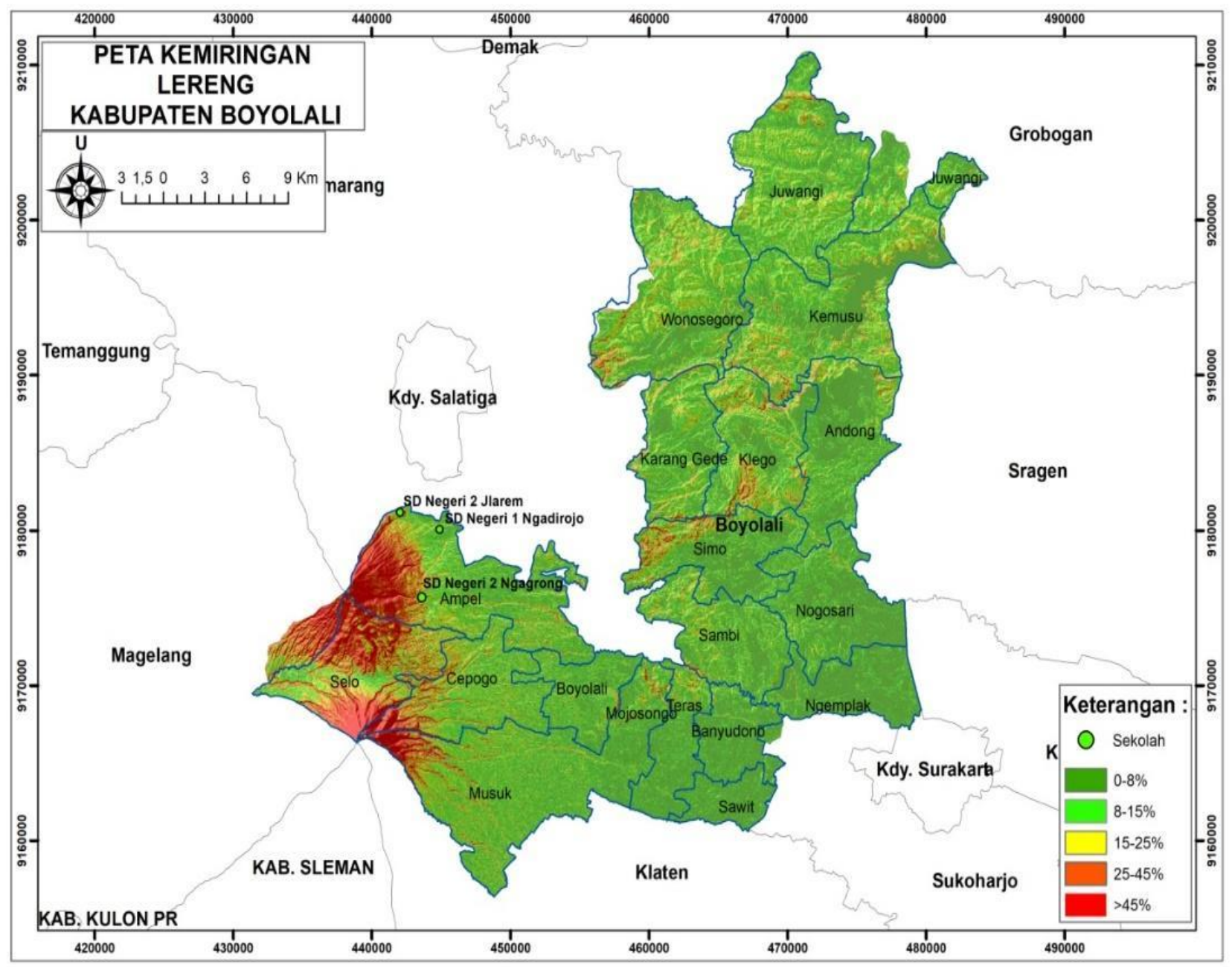

Figure 2. Slope Map in Boyolali Regency 


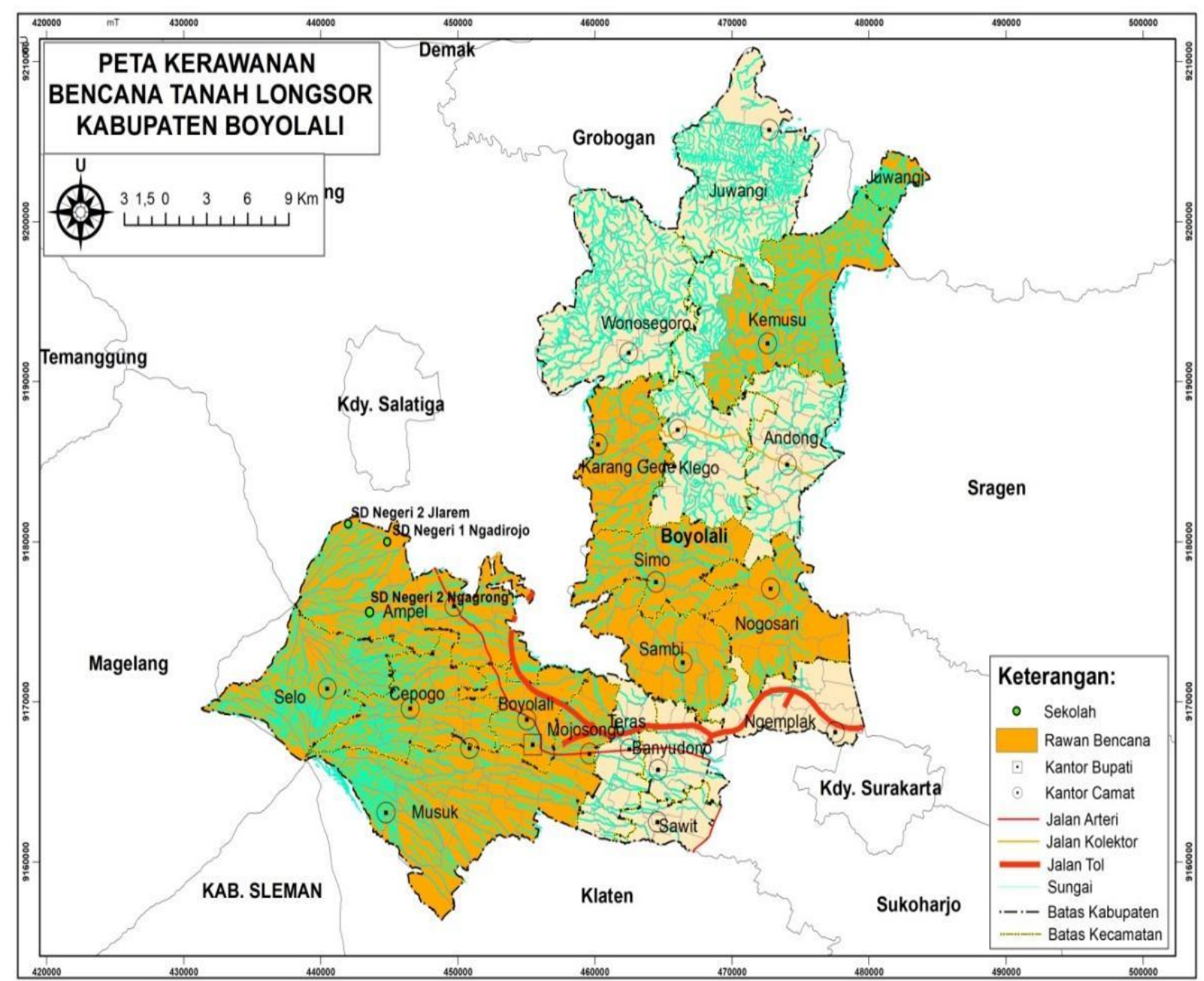

Figure 3. Landslide Hazard Map in Boyolali Regency

\section{FINDINGS AND DISCUSSION Regional Physical Conditions}

The units of analysis were determined based on van Zuidam's classification of slope classes (Figure 1). SD Negeri (Public Elementary School) 1 Ngadirojo is located on an $8-10 \%$ slope area (sloping), SD Negeri 2 Jlarem is located on a $15-25 \%$ slope area (moderate steep), while SD Negeri 2 Ngagrong is located on a $25-45 \%$ slope area (steep). The slope is one of the parameters used to identify landslide vulnerability in the three sample schools (Putri, 2016). The more gentle the slope is, the lower the potential for landslides to occur (Fitrianingrum, 2018). The three schools used in this study are located in areas prone to landslides (Figure 3).

\section{Policy Indicators}

The analysis of the vulnerability of the school environment in this study was carried out based on the analysis of four indicators, namely indicators of school policies, facilities and infrastructure, knowledge, and structure. There are differences in vulnerability classes in each school based on the indicators of vulnerability. In school policy indicators, there are three classes of vulnerability, namely high vulnerability class (SD Negeri 1 Ngadirojo), medium vulnerability class (SD Negeri 2 Jlarem), and low vulnerability class (SD Negeri 2 Ngagrong) (Table 3).

The school policy analysis was carried out based on the parameters in the questionnaire distributed to the respondents. The questionnaire used consists of 22 statements and questions related to disasters. Respondents at SD Negeri 1 Ngadirojo stated that of the 22 questions and statements there were only three policies regarding disasters at SD Negeri 1 Ngadirojo that had been implemented. The three parameters are the integration of disaster material into subjects, extracurricular activities based on 
preparedness, and the intellectual enhancement of teachers regarding disasters. The disaster policy at SD Negeri 1 Ngadirojo is classified as limited, thus making SD Negeri 1 Ngadirojo a high vulnerability class.

The vulnerability of SD Negeri 2 Jlarem is included in the medium class based on the number of scores obtained (Table 3). The vulnerability class of SD Negeri 2 Ngagrong is lower than SD Negeri 1 Ngadirojo and SD Negeri 2 Jlarem. This is because SD Negeri 1 Ngadirojo and SD Negeri 2 Jlarem do not have a disaster simulation program. SD Negeri 2
Ngagrong conducted a disaster simulation in collaboration with PMI Boyolali Regency. The participation of SD Negeri 2 Ngagrong in the disaster simulation activity indicates that the school is grave in disaster mitigation. Integration of disaster knowledge into learning in schools is an effective form of disaster mitigation. This can increase the capacity of school residents in the elementary school environment. The absence of school policies in disaster management can increase the vulnerability of a school.

Table 3. Landslide Vulnerability Class in Policy Indicators

\begin{tabular}{cccc}
\hline No. & Schools & Vulnerability level & Score \\
\hline 1 & SD Negeri 1 Ngadirojo & High & 9 \\
2 & SD Negeri 2 Jlarem & Moderate & 26 \\
3 & SD Negeri 2 Ngagrong & Low & 45 \\
\hline
\end{tabular}

Source: Data analysis (2021)

\section{Facilities and Infrastructure Indicators}

The next indicator of environmental vulnerability is facilities and infrastructure. Table 4 showed the result of the vulnerability analysis of facilities and infrastructure owned by elementary schools in the Boyolali Regency. There are three classes of vulnerability based on infrastructure and facilities indicators. The vulnerability class owned by SD Negeri 1 Ngadirojo is the high vulnerability class. This is because the facilities and infrastructure related to landslides at SD Negeri 1 Ngadirojo are not yet fully available. Furthermore, the school has a medium vulnerability class in SD Negeri 2 Jlarem. The facilities and infrastructure available for landslides at SD Negeri 2 Jlarem are more adequate than at SD Negeri 1 Ngadirojo. Based on the results of the interview, SD Negeri 2 Jlarem has an important telephone number that is easily accessible to all school components, such as hospital and police phone numbers, while SD Negeri 1 Ngadirojo in contacting the hospital and police through a third party, namely the village head near the school. SD Negeri 2 Ngagrong has low vulnerability because the availability of supporting facilities and infrastructure for landslide disaster mitigation is quite adequate. One of them is the availability of shelters closest to schools that are not owned by SD Negeri 1 Ngadirojo and SD Negeri 2 Jlarem.

Table 4. Vulnerability to Landslides in Facilities and Infrastructure Indicators

\begin{tabular}{cccc}
\hline No. & Schools & Vulnerability level & Score \\
\hline 1. & SD Negeri 1 Ngadirojo & High & 11 \\
2. & SD Negeri 2 Jlarem & Moderate & 14 \\
3. & SD Negeri 2 Ngagrong & Low & 22 \\
\hline
\end{tabular}

Source: Data analysis (2021)

\section{Knowledge Indicators}

The next indicator is the knowledge of principals and teachers (Table 5). SDN 1 Ngadirojo has a high level of vulnerability because the level of knowledge of school residents about landslides is low. Based on the results of observations, physically the location of SDN 1 Ngadirojo has a relatively sloping topography. It causes SDN 1 Ngadirojo potentially to be affected by landslides is low, so that the level of knowledge of school residents about landslides is also low. 
Furthermore, the level of knowledge possessed by SD Negeri 2 Jlarem school residents regarding landslide disaster mitigation is moderate. This is because SD Negeri 2 Jlarem is located on the slopes of Merbabu Volcano which has a high potential for landslides. Therefore, SD Negeri 2 Jlarem has better knowledge of landslides than SD Negeri 1 Ngadirojo.

Different results were obtained at SDN 2 Ngagrong which belongs to the low vulnerability class. This is because the level of knowledge about landslides owned by school principals and teachers is high. One of the very influential things is the location of the school which is located in an area with a slope of $40 \%$ and has the potential to be exposed to landslides. Therefore, education and socialization regarding landslide disasters received by the SDN 2 Ngagrong community from both the government and nongovernmental organizations are more intensive than other schools.

Table 5. Landslide Vulnerability Level in Knowledge Indicator

\begin{tabular}{rlcc}
\hline No. & \multicolumn{1}{c}{ Schools } & Vulnerability level & Score \\
\hline 1. & SD Negeri 1 Ngadirojo & High & 267 \\
2. & SD Negeri 2 Jlarem & Moderate & 289 \\
3. & SD Negeri 2 Ngagrong & Low & 298 \\
\hline
\end{tabular}

Source: Data analysis (2021)

\section{Indicator of School Building Structure}

Another indicator used is the structural indicator of school buildings. The results of the vulnerability analysis based on structural indicators are based on the results of a questionnaire that was validated in the field by observing the physical condition of the school (Table 6). Based on its structural conditions, SDN 2 Ngagrong has high vulnerability because the structural conditions of the school are inadequate. Structural aspects that are lacking, such as not having a building design that is safe from landslides, the location of the school building is on the edge of the slope.

The building blocks of the school walls are lightweight so that the beams and walls in the building are prone to damage such as cracks, breaks, and loose from their bonds. Furthermore, financially SDN 2 Ngagrong does not have a sufficient budget for routine maintenance of school buildings. Structural policies have a role to play in overcoming high vulnerability to landslides. This is because inadequate structural conditions can threaten the safety of the school community if landslides occur during teaching and learning activities. Furthermore, SDN 2 Jlarem has a moderate level of vulnerability based on the results of questionnaires and field observations. SDN 1 Ngadirojo has a low level of vulnerability because structurally SDN 1 Ngadirojo has a better school building structure.

Table 6. Landslide Vulnerability Level in Structure Indicator

\begin{tabular}{rlcc}
\hline No. & \multicolumn{1}{c}{ Schools } & Vulnerability level & Score \\
\hline 1. & SD Negeri 2 Ngagrong & High & 11 \\
2. & SD Negeri 2 Jlarem & Moderate & 12 \\
3. & SD Negeri 1 Ngadirojo & Low & 16 \\
\hline
\end{tabular}

Source: Data analysis (2021)

\section{Elementary School Environmental Vulnerability}

The accumulation of the four vulnerability indicators results in the total vulnerability class of the school environment (Table 7). The results of the analysis of the environmental vulnerability level of elementary schools to landslides in Boyolali
Regency obtained three levels of the total vulnerability of the school environment. The vulnerability levels of the school environment to landslides in Table 7 include high, medium, and low vulnerability levels. The school with high vulnerability level in SD Negeri 1 Ngadirojo, the school environment vulnerability with the medium level in SD 
Negeri 2 Jlarem, while the vulnerability of the school environment with low level is SD Negeri 2 Ngagrong. The results of the analysis show that there are variations in the vulnerability of the elementary school environment to landslides based on the slope class.

SD Negeri 1 Ngadirojo is located on a gentle slope area. It makes SD Negeri 1 Ngadirojo have a small potential for landslides to occur, so schools pay less attention and prepare for landslide disaster mitigation. Lack of preparedness for landslides has made SD Negeri 1 Ngadirojo included in a high environmental vulnerability level. The level of vulnerability is influenced by the impact of losses arising from a particular hazard (Gougelet, 2016). If one day SD Negeri 1 Ngadirojo is exposed to landslides, the impact of the losses will be severe. Furthermore, schools that are in a class with a rather steep slope, namely SD Negeri 2 Jlarem, have a moderate environmental vulnerability level. SD Negeri 2 Jlarem has adequate awareness and preparedness for landslides, although there are still things that need to be improved, such as supporting facilities and infrastructure (maps and evacuation routes, hazard warning system tools, disaster training sites, emergency stairs). SD Negeri 2 Ngagrong is located on a steep slope area where the terrain of this school is quite extreme. SD Negeri 2 Ngagrong is preparing for landslide preparedness well, so SDN 2 Ngagrong has a low level of vulnerability to landslides. If a school has a high vulnerability level, the potential for landslides to occur will be even greater (Nursa'ban, 2010).

Table 7. Landslide Vulnerability Level in Environmental Indicators

\begin{tabular}{cccc}
\hline No. & Schools & Vulnerability level & Score \\
\hline 1. & SD Negeri 1 Ngadirojo & High & 303 \\
2. & SD Negeri 2 Jlarem & Moderate & 341 \\
3. & SD Negeri 2 Ngagrong & Low & 376 \\
\hline
\end{tabular}

Source: Data analysis (2021)

\section{Landslide Disaster Mitigation Planning for Elementary Schools}

Based on the vulnerability analysis of landslides in Elementary Schools (SD) in the Boyolali District, schools need to carry out planning related to disaster mitigation. The implementation of disaster mitigation in the basic education environment is the responsibility of school residents including all community components and community institutions or institutions around the school (Ndama, Umar, Ismunandar, \& Suardana, 2019). Disaster mitigation planning can be carried out by integrating disaster education, especially landslides, with subjects such as Social Sciences, Natural Sciences, Islamic Religious Education, and local content as well as extracurricular activities, such as Praja Muda Karana (PRAMUKA) and the Youth Red Cross (PMR). Strategies that can be carried out by teachers are mapping basic competencies in each subject and determining indicators and considering potential disasters (Suarmika \& Utama, 2017). Furthermore, schools can increase the knowledge of the school community through counseling, training, and simulations regarding landslides which can be done by building cooperation with the Regional Disaster Management Agency (BPBD) and the Education Office or nearby universities. Disaster education can form mentality and awareness in taking appropriate actions when a disaster occurs, as well as after a disaster to minimize disaster victims (Ansori \& Santoso, 2020; Marfai, Cahyadi, Fatchurohman, Rosaji, \& Wibowo, 2019; Ratu Nabillah, Iwan Setiawan, \& Bagja Waluya, 2020). The ability of the school to understand and know about landslide disasters can be channeled to students to create wise attitudes of students in dealing with disasters, through simulation methods so that students can understand the concepts, principles, and skills of disaster (Novarita, Sugandi, \& Pasya, 2016; Priyono, 2016). Besides, strengthening school buildings (retrofitting) by proposing repairs to the government, so that the building structure becomes stronger (Rosyidin et al., 2019). Schools also need to prepare Disaster Management Plan (RPB) documents. RPB preparation can be done by compiling contingency plans, regular procedures, and 
integrating disaster materials into the school curriculum.

\section{CONCLUSIONS}

Based on the data analysis, it can be concluded that the location of the school in the landslide-prone area of the Boyolali Regency is not directly proportional to the condition of its vulnerability. SD Negeri 1 Ngadirojo, which is located in an area with a gentle slope, has a high level of vulnerability due to a lack of preparedness. There is no education regarding emergency response, no rescue protocols, and school buildings have not been designed according to disaster-prepared school standards. SD Negeri 2 Jlarem which is on a moderately steep slope has a moderate level of vulnerability due to fairly good school preparedness, such as school construction that takes into account the level of disaster-prone. SD Negeri 2 Ngagrong is on a steep slope with a low level of vulnerability because it has high preparedness and is relatively better prepared to face the threat of disasters. This research is limited to a vulnerability analysis based on policy indicators, facilities and infrastructure, knowledge, and structural conditions of school buildings as a basis for disaster mitigation planning. Furthermore, the research implementation did not cover all KRB landslides in the Boyolali Regency. Therefore, it is hoped that this research can become one of the bases for further researchers to be able to compile a broader scope of research with a more detailed sample so that landslide disaster mitigation planning can be structured and wellplanned.

\section{RECOMMENDATIONS}

This research is expected to be one of the bases for further researchers to be able to compile a wider scope of research covering all KRB landslides in the Boyolali Regency. This is to increase capacity in the elementary school environment, so that disaster risk can be reduced. Schools with good capacity can support disaster resilience programs on a national scale.

\section{REFERENCES}

Alimohammadlou, Y., Najafi, A., \& Yalcin, A. (2013). Landslide process and impacts:
A proposed classification method. Catena, Vol. 104, pp. 219-232. https://doi.org/10.1016/j.catena.2012.11 .013

Ansori, M. H., \& Santoso, M. B. (2020). Pentingnya Pembentukan Program Sekolah Siaga Bencana Bagi Kabupaten Bandung Barat. Prosiding Penelitian Dan Pengabdian Kepada Masyarakat, 6(3), https://doi.org/10.24198/jppm.v6i3.229 75

Benson, L., \& Bugge, J. (2007). Child-led disaster risk reduction: A practical guide. UK.

Chen, C. Y., \& Lee, W. C. (2012). Damages to school infrastructure and development to disaster prevention education strategy after Typhoon Morakot in Taiwan. Disaster Prevention and Management: An International Journal, 21(5), 541555.

https://doi.org/10.1108/0965356121127 8680

Cruden, D. M., \& Varnes, D. J. (1996). Landslide types and processes. Special Report - National Research Council, Transportation Research Board, 247, 36-75.

Doocy, S., Russell, E., Gorokhovich, Y., \& Kirsch, T. (2013). Disaster preparedness and humanitarian response in flood and landslide-affected communities in Eastern Uganda. Disaster Prevention and Management: An International Journal, 22(4), 326339. https://doi.org/10.1108/DPM-102012-0108

Fitrianingrum, M. E. (2018). Zonasi Rawan Longsor Di Desa Pagerharjo Kecamatan Samigaluh Kabupaten Kulonprogo Yogyakarta. Jurnal Geografi Gea, 18(2), 181. https://doi.org/10.17509/gea.v18i2.8481 
Gougelet, R. M. (2016). Disaster mitigation. In Ciottone's Disaster Medicine (2nd Editio, pp. 160-166). https://doi.org/10.1016/B978-0-32328665-7.00027-3

Istijono, B., Hakam, A., \& Ophiyandri, T. (2016). Landslide hazard of Maninjau area. International Journal of Disaster Resilience in the Built Environment, 7(3), $302-312$. https://doi.org/10.1108/IJDRBE-042014-0027

Kazeev, A., \& Postoev, G. (2017). Landslide investigations in Russia and the former USSR. Natural Hazards, 88(s1), 81-101. https://doi.org/10.1007/s11069-0162688-z

Li, L., Chu, X., \& Yu, G. (2019). Cohesive slope failure analysis using methods combining smoothed particle hydrodynamics and response surface function. Engineering Computations (Swansea, Wales), 37(3), 1093-1108. https://doi.org/10.1108/EC-03-20190118

Makajić-Nikolić, D. (2020). Disaster Risk Reduction. 378-389. https://doi.org/10.1007/978-3-31995885-9_65

Marfai, M. A., Cahyadi, A., Fatchurohman, H., Rosaji, F. S. C., \& Wibowo, Y. A. (2019). Tsunami preparedness and environmental vulnerability analysis in Kukup Beach, Gunungkidul, Indonesia. IOP Conference Series: Earth and Environmental Science, 256(1). https://doi.org/10.1088/17551315/256/1/012025

Mohamed Shaluf, I. (2007). An overview on disasters. Disaster Prevention and Management: An International Journal, 16(5), 687-703. https://doi.org/10.1108/0965356071083 7000
Naryanto, H. S., Prawiradisastra, F., Ardiyanto, R., \& Hidaya, W. (2020). Analisis Pasca Bencana Tanah Longsor 1 Januari 2020 dan Evaluasi Penataan Kawasan di Kecamatan Sukajaya, Kabupaten Bogor. Jurnal Geografi Gea, 20(2), 197-213. https://doi.org/https://doi.org/10.17509/ gea.v20i2.24232.g13239

Ndama, M., Umar, N., Ismunandar, \& Suardana, I. K. (2019). Pelatihan Siaga Bencana Pada Anak Sekolah Dasar Di SD $N 7$ Labuan Baru Mamboro Palu Utara. Jurnal Pengabmas Masyarakat Sehat, 1(4), 250-255.

Novarita, A., Sugandi, D., \& Pasya, G. K. (2016). Peranan Pembelajaran Geografi Dalam Pembentukan Sikap Peserta Didik Terhadap Mitigasi Bencana Gempa Bumi dan Longsor di Kota Padang. Jurnal Geografi Gea, 15(1), 5563.

https://doi.org/10.17509/gea.v15i1.4185

Nursa'ban, M. (2010). Identifikasi Kerentanan dan Sebaran Longsor Lahan Sebagai Upaya Mitigasi Bencana di Kecamatan Bener Kabupaten Purworejo. Jurnal Geografi Gea, 10(2), $1-12$.

https://doi.org/https://doi.org/10.17509/ gea.v10i2.1018.g670

Paimin, S., \& Pramono, I. B. (2009). Teknik mitigasi banjir dan tanah longsor. In Tropenbos International Indonesia Programme, Indonesia. Balikpapan: Tropenbos International Indonesia Programme.

Paudel, P. P., Omura, H., Kubota, T., \& Morita, K. (2003). Landslide damage and disaster management system in Nepal. Disaster Prevention and Management: An International Journal, 12(5), 413-419. https://doi.org/10.1108/0965356031050 7235 
Pourghasemi, H. R., Gayen, A., Edalat, M., Zarafshar, M., \& Tiefenbacher, J. P. (2020). Is multi-hazard mapping effective in assessing natural hazards and integrated watershed management? In Geoscience Frontiers, Vol. 11, China University of Geosciences (Beijing). https://doi.org/10.1016/j.gsf.2019.10.00 8

Priyono, A. (2016). Pengaruh Metode Simulasi dan Demonstrasi Terhadap Pemahaman Konsep Bencana Tanah Longsor (Study Eksperimen Pada Peserta Didik Kelas X SMA Negeri 1 Sirampog). Jurnal Geografi Gea, 14(2), 78-91.

https://doi.org/10.17509/gea.v14i2.3398

Ratu Nabillah, Iwan Setiawan, \& Bagja Waluya. (2020). Kerentanan Sosial pada Wilayah Potensi Bencana Tsunami di Pesisir Kecamatan Rajabasa Kabupaten Lampung Selatan. Jurnal Geografi, Edukasi Dan Lingkungan (JGEL), 4(2), 96-112.

https://doi.org/10.29405/jgel.v4i2.4318

Ray-Bennett, N. S., \& Shiroshita, H. (2019). Disasters, deaths and the Sendai Framework's target one: A case of systems failure in Hiroshima Landslide 2014, Japan. Disaster Prevention and Management: An International Journal, 28(6), 764-785. https://doi.org/10.1108/DPM-09-20190302

Rizaldy, D. (2018). Implementasi Pendidikan Mitigasi Bencana di Sekolah-Sekolah di Indonesia Sebagai Upaya Pembentukan Karakter Siswa Siap Siaga. PROSIDING PIT KE-5 RISET KEBENCANAAN IABI, 479-487. Padang. Retrieved from https://docplayer.info/99461634-

Implementasi-pendidikan-mitigasibencana-di-sekolah-sekolah-diindonesia-sebagai-upaya-pembentukankarakter-siswa-siap-siaga.html
Rosyidin, W. F., Dahlia, S., Zahro, A. A., Pangestu, A. R., Katami, M., \& Najiyullah, M. A. (2019). Identifikasi Multi Bahaya di Area Pendidikan Muhammadiyah dengan Metode VISUS di Jakarta. Jurnal Geografi, Edukasi Dan Lingkungan (JGEL), 3(1), 18. https://doi.org/10.29405/jgel.v3i1.2989

Shaw, R., \& Tran, P. (2012). Climate change issues in education sectors: An environmental entry point of risk reduction. In Community, Environment and Disaster Risk Management, Vol. 9, Emerald Group Publishing Ltd. https://doi.org/10.1108/S20407262(2012)0000009021

Shiwaku, K., \& Fernandez, G. (2011). Roles of School in Disaster Education. In Disaster Education, vol. 7, pp. 45-75. Emerald Group Publishing Limited. https://doi.org/doi:10.1108/S20407262(2011)0000007009

Shiwaku, K., Shaw, R., Kandel, R. C., Shrestha, S. N., \& Dixit, A. M. (2007). Future perspective of school disaster education in Nepal. Disaster Prevention and Management: An International Journal, 16(4), 576-587. https://doi.org/10.1108/0965356071081 7057

Singh, A. K. (2009). Causes of slope instability in the Himalayas. Disaster Prevention and Management: An International Journal, 18(3), 283-298. https://doi.org/10.1108/0965356091096 5646

Singh, A. K. (2010). Landslide management: Concept and philosophy. Disaster Prevention and Management: An International Journal, 19(1), 119-134. https://doi.org/10.1108/0965356101102 2180

Suarmika, P. E., \& Utama, E. G. (2017). Pendidikan Mitigasi Bencana di Sekolah Dasar (Sebuah Kajian Analisis Etnopedagogi). JPDI (Jurnal Pendidikan 
Dasar Indonesia), 2(2), 18. https://doi.org/10.26737/jpdi.v2i2.327

Susilo, A., Fitriah, F., Sunaryo, Ayu Rachmawati, E. T., \& Suryo, E. A. (2020). Analysis of landslide area of Tulung subdistrict, Ponorogo, Indonesia in 2017 using resistivity method. Smart and Sustainable Built Environment, 9(4), 341-360.

https://doi.org/10.1108/SASBE-062019-0082

Tran, P., Kaneko, F., Shaw, R., Victoria, L. P., \& Oi, H. (2009). Chapter 2: Urban disaster risk analysis, action planning and implementation management. In Community, Environment and Disaster Risk Management (Vol. 1). Elsevier. https://doi.org/10.1108/S20407262(2009)0000001006

Undang-undang Republik Indonesia Nomor 24 Tahun 2007 tentang Penanggulangan Bencana. (2007). https://doi.org/10.23943/978140088987 7

UNISDR. (2009). UNISDR Terminology on Disaster Risk Reduction. Geneva, Switzerland: United Nations.
Wibowo, Y. A., Dewi, R. P., Ronggowulan, L., Anjarsari, R. Y., \& Miftakhunisa, Y. (2020). Penguatan Literasi Mitigasi Bencana Angin Puting Beliung untuk Peningkatan Kapasitas Masyarakat Desa Munggur, Kabupaten Boyolali, Jawa Tengah. Warta LPM, 23(2), 165179.

https://doi.org/10.23917/warta.v23i2.10 571

Wibowo, Y. A., Ronggowulan, L., Arif, D. A., Afrizal, R., Anwar, Y., \& Fathonah, A. (2019). Perencanaan Mitigasi Bencana Banjir Non-Struktural Di Daerah Aliran Sungai Comal Hilir, Jawa Tengah. JPIG (Jurnal Pendidikan Dan Ilmu Geografi), 4(2), 87-100. https://doi.org/10.21067/jpig.v4i2.3632

Zhou, X., \& Sun, Z. (2019). Quantitative assessment of landslide risk using Monte Carlo material point method. Engineering Computations (Swansea, Wales), 37(5), 15771596. https://doi.org/10.1108/EC-04-20190186 